\title{
Evaluating Host Resistance to Limit Colletotrichum coccodes on Onion
}

\author{
Lina M. Rodríguez-Salamanca ${ }^{1}$ and Mary K. Hausbeck ${ }^{2,3}$ \\ Department of Plant, Soil, and Microbial Sciences, Michigan State \\ University, East Lansing, MI 48824
}

Additional index words. Allium cepa, anthracnose, cultivars, disease resistance

\begin{abstract}
Leaf and neck anthracnose is incited by Colletotrichum coccodes (Wallr.) Hughes, a new foliar disease of onion (Allium cepa L.) in Michigan that has been observed in the state since 2010. Symptoms include elliptical lesions on the leaves, necks, or both that appear bleached with a pale salmon to dark brown center. To develop an effective integrated disease management strategy, field studies were conducted in 2011 and 2012 to evaluate 16 commercial onion cultivars for their susceptibility to the pathogen. The incidence and severity of anthracnose were evaluated weekly following inoculation. Onion cultivars differed significantly in disease severity and incidence; differences between years were also observed. 'Hendrix' had the lowest disease severity, whereas 'Highlander' and 'Candy' exhibited severe onion leaf and neck anthracnose symptoms. Using less susceptible onion cultivars combined with effective fungicides against $C$. coccodes may limit crop losses for Michigan growers.
\end{abstract}

A range of pathogens can compromise onion quality and yield (Carisse et al., 2011; Develash and Sugha, 1997; Schwartz and Mohan, 1995, 2008) and are a yearly threat in Michigan. Onion leaf and neck anthracnose incited by $C$. coccodes (Wallr.) Hughes was recently reported as a new disease, and growers in many Michigan counties observed significant symptoms in 2010 (RodríguezSalamanca et al., 2012) and continue to see symptoms yearly (Hausbeck, personal observation). The symptoms of onion leaf and neck anthracnose incited by $C$. coccodes (Rodríguez-Salamanca et al., 2012) are different from the symptoms incited by Colletotrichum gloeosporioides (Penz.) Penz. \& Sacc previously reported in the United States and the tropics, which is referred to as onion twister (Ebenebe, 1980; Nischwitz et al., 2008; Schwartz et al., 2015) or anthracnose (Galvan, 2010; Haddad et al., 2003). Onion leaf and neck anthracnose symptoms include oval lesions on the leaves and neck that differ in appearance from other commonly occurring onion foliar diseases (Schwartz and Mohan, 1995). The onion leaf and neck anthracnose lesions range about from 0.2 to $0.6 \mathrm{~cm}$ in width $\times 0.4$ to $3 \mathrm{~cm}$ in length and have a characteristic bleached appearance that includes a salmon- to brown-colored center.

Received for publication 6 Feb. 2018. Accepted for publication 3 May 2018.

This work was supported by MSU GREEEN GR11-030 and GR11-020 and the Michigan Onion Committee.

We thank all the members of the Hausbeck Lab for their valuable help; special thanks to A. Worth and J. Munoz for guidance with statistical analysis assistance.

${ }^{1}$ Former Graduate Research Assistant.

${ }^{2}$ Professor.

${ }^{3}$ Corresponding author. E-mail: hausbec1@msu. edu.
Environmental conditions especially conducive to onion leaf and neck anthracnose include a minimum of $12 \mathrm{~h}$ at high relative humidity with temperatures higher than $20^{\circ} \mathrm{C}$ (Rodríguez-Salamanca et al., 2018). On tomato, severe disease incidence incited by $C$. coccodes is most often associated with high rainfall during the growing season (Dillard, 1989). Disease incidence may also be increased by the use of overhead irrigation (Raniere and Crossan, 1959).

C. coccodes has been reported to infect 50 different hosts worldwide (Farr and Rossman, 2011) and 18 within the United States and is of primary importance on tomato (Dillard, 1992) and potato [Tsror (Lahkim) and Johnson, 2000]. Seed extracted from tomato fruit infected with $C$. coccodes may also be infested with the pathogen (Ben-Daniel et al., 2010). $C$. coccodes can also infect weed species in the families Amaranthaceae, Asteraceae, Brassicaceae, Euphorbiaceae, Poaceae, Malvaceae, Oxalidaceae, and Polygonaceae (Anderson and Walker, 1985; Raid and Pennypacker, 1987). The pathogen produces abundant acervuli and sclerotia on senescent tissues of infected plants including tomato (Dillard and Cobb, 1998), potato (Nitzan et al., 2008), and some weed species (Raid and Pennypacker, 1987). Acervuli give rise to abundant black globose microsclerotia that have setae (Sutton, 1980). Conidia are produced from acervuli and moisture from rain or irrigation is necessary for their release (Dillard, 1992). Sclerotia may remain in the soil for up to 1 year in potato fields [Farley, 1976; Tsror (Lahkim) and Johnson, 2000] and survive associated with host debris or alone for up to 8 years in tomato fields (Dillard and Cobb, 1998).

About 40 onion cultivars are available to Michigan growers from various seed suppliers. Some of these cultivars offer resistance to pink root incited by Setophoma terrestris (H.N. Hansen) Gruyter, Aveskamp, \& Verk- ley (Syn: Phoma terrestris) and Fusarium basal rot incited by Fusarium oxysporum $\mathrm{f}$. sp. cepae (H.N. Hansen) W.C. Snyder \& H.N. Hansen, but their response to $C$. coccodes has not been evaluated. The occurrence of this pathogen constitutes a new challenge for onion growers in Michigan in maintaining productivity and profitability and an integrated disease management strategy is needed. Onion growers historically have rotated with celery or carrot which are not recognized hosts of $C$. coccodes and apply fungicides including strobilurin products which were shown to limit disease in a field study (RodríguezSalamanca, 2013). In this study, we sought to investigate the response of 16 onion cultivars to $C$. coccodes to limit leaf and neck anthracnose under Michigan field conditions.

\section{Materials and Methods}

Field preparation, plant establishment, and field maintenance. Cultivar trials were direct-seeded in mineral soil, Oakville fine sand (Natural Resources Conservation Serv., n.d.), at the Southwest Michigan Research and Extension Center, Benton Harbor, MI, on 27 May 2011 and 10 May 2012. The field was previously planted to rye and vetch cover crops in 2010 and to onion (C. coccodesinoculated plots) in 2011. Although Michigan onions are produced primarily on muck soils, some growers have moved a portion of their acreage to mineral soils to avoid pink root disease. Before bedding, $560 \mathrm{~kg} \cdot \mathrm{ha}^{-1}$ of 8-21-29 fertilizer was applied with micronutrients $(0.5 \% \mathrm{Cu}, 1 \% \mathrm{Mn}$ and $0.5 \% \mathrm{Zn})$ and side-dressed twice with $11 \mathrm{~kg} \cdot \mathrm{ha}^{-1}$ of foliar 20-20-20 fertilizer. The target seeding density was 18 plants per $30 \mathrm{~cm}$. Onion cultivars tested for their susceptibility to $C$. coccodes under field conditions during 2011 and 2012 included one red-colored bulb cultivar (Redwing) and 15 yellow-colored bulb cultivars (Table 1). The 16 commercially available cultivars were planted in a randomized complete block design (RCBD) with four blocks. Each block was $5 \mathrm{~m}$ long and consisted of a double row spaced $38 \mathrm{~cm}$ apart. A plot consisted of a double row of onions spaced 38 cm apart.

Weed control was achieved by hand weeding and herbicides were applied as needed following current recommendations (Bird et al., 2012). Insects, including thrips and armyworms, were controlled with applications of methomyl $\left(2.3 \mathrm{~L} \cdot \mathrm{ha}^{-1}\right)$. The plants had overhead mist irrigation (94.6 L.ha ${ }^{-1}$ ) $2 \mathrm{~d}$ each week for $1-2 \mathrm{~h}$ to promote leaf wetness conducive to $C$. coccodes dispersal and infection in the field.

Inoculum preparation, inoculation, and disease ratings. Several C. coccodes isolates recovered from onion leaves in 2010 and maintained in long-term storage in the Hausbeck laboratory culture collection were used as inoculum. The Michigan C. coccodes isolates 7-1-1-3 (Newaygo Co.), 8-1-1-1 (Ottawa Co.), 24-1-1-2 (Ionia Co., NRRL accession number 62808), 31-1-2-2 (Calhoun Co.), 34-1-6-1 (Kent Co.), and 38-1-3-1 
(Eaton Co., NRRL accession number 62809) were obtained from infected and symptomatic foliage of onions.

Isolates were transferred from long-term storage onto $50 \%$ strength potato dextrose agar (PDA) and incubated at $22 \pm 2{ }^{\circ} \mathrm{C}$ for $7 \mathrm{~d}$. A total of 120 plates (20 plates per isolate) with at least 70 -mm-diameter fungal growth was blended with $\approx 500 \mathrm{~mL} 0.001 \%$ tween in water and strained through a $19-\mathrm{L}$ paint strainer. This process was repeated until all 120 fungal plates were used. A total of $25 \mathrm{~L}$ of inoculum was prepared per trial. The conidial suspension was adjusted to $2 \times 10^{5}$ conidia/mL (Rodríguez-Salamanca et al., 2018) and placed in plastic carboys (Nalgene, Rochester, NY). An earlier study indicated that this inoculum concentration could result in $\approx 40 \%$ disease severity under controlled and optimized environmental conditions (Rodríguez-Salamanca et al., 2018). Inoculum was applied twice during the growing season on 21 July and 25 Aug. 2011, and 12 July and 7 Aug. 2012. The conidial suspension was applied using a $\mathrm{CO}_{2}$ backpack sprayer (R\&D Sprayer, Opelousas, LA) with a two-nozzle boom. The boom was equipped with two Teejet extended-range flat nozzles (XR8002) spaced $40 \mathrm{~cm}$ apart and calibrated to deliver $473 \mathrm{~L} \cdot \mathrm{ha}^{-1}$ at $344 \mathrm{kPa}$.

Disease assessment. The number of plants with leaf and neck lesions (incidence) and severity of disease was evaluated in the inner $4 \mathrm{~m}$ of each plot. Disease severity was evaluated using a 0 to 5 disease rating scale based on the percentage of onion foliage (including the necks) covered with lesions using the following scale: $0=$ no symptoms, $1=>0 \%$ to $10 \%, 2=>10 \%$ to $25 \%, 3=>25 \%$ to $50 \%, 4=>50 \%$ to $75 \%$, and $5=>75 \%$ to $100 \%$. Plots were rated weekly, beginning 14 $\pm 2 \mathrm{~d}$ after inoculation (DAI), until 56 DAI. Plots were not harvested as yield comparisons among cultivars were not the purpose of this study. A field study with 'Infinity' onion indicated that total yield could be decreased by nearly $30 \%$ when onions were not protected with an effective fungicide treatment and then inoculated with $C$. coccodes (Rodríguez-Salamanca, 2013).

Pathogen reisolation and confirmation. At the end of the trial, five plants per plot and block were sampled by isolating from tissue at the healthy-diseased interface of lesions visible on the leaves. Tissue was plated onto $50 \%$ strength PDA amended with $30 \mathrm{ppm}$ rifampicin and $100 \mathrm{ppm}$ ampicillin and maintained at $22 \pm 2{ }^{\circ} \mathrm{C}$ under continuous fluorescent light. Five days after plating, fungal colonies were observed for the macroscopic appearance and microscopic characteristics corresponding to $C$. coccodes (Hughes, 1958; Robert et al., 2005). Plates were then incubated under the conditions as previously described for nine additional days and then observed for the presence of microsclerotia.

Onion roots from the sampled plants were inspected for the presence of microsclerotia. Roots were surface disinfested with $1 \%$ sodium hypochlorite solution for $3 \mathrm{~min}$, rinsed three times with distilled water, and allowed to air dry for $1 \mathrm{~h}$. Isolations were conducted on $25 \%$ strength PDA and cultures were incubated at $22 \pm 2{ }^{\circ} \mathrm{C}$ for $14 \mathrm{~d}$ under continuous light.

Statistical analysis. Final disease incidence was analyzed using a generalized linear model with a Logit link function and binomial distribution. Incidence and severity values were used to calculate the area under the disease progress curve (AUDPC); IAUDPC and SAUDPC for incidence and severity, respectively, and yield was analyzed using the PROC MIXED and PROC GLIMMIX procedure of the SAS statistical analysis software (SAS Institute, Inc., Cary, NC) using a RCBD model. Data were tested for normality (q-q plots and the ShapiroWilk test) and homogeneity of variance (Levene's test) of the residuals. The need to include a covariate in the model was tested and used. Models analysis of variance and analysis of covariance (ANCOVA) were evaluated using the type III effects output. Significant differences were subject to grouping by least significant differences $(P<0.05$ or $P<0.1)$.

\section{Results}

Leaf and neck anthracnose symptoms were observed 14 and 16 DAI in 2011 and 2012, respectively. Final disease incidence ranged from $30.4 \%$ to $94.9 \% 49$ DAI (2011) and $41.0 \%$ to $64.7 \% 47$ DAI (2012) (Table 1). In general, the lesions were oval in shape with the affected tissue appearing to be bleached or light green. The pathogen sporulation in the center of the lesion initially appeared to be pale pink to salmon in color and then progressed to brown as the lesion aged. An uneven plant stand due to variable germination was observed among cultivars in $2011(P<0.001)$ but not in $2012(P=0.056)$. Final onion leaf and neck anthracnose incidence varied between years $(P<0.001)$ and cultivars $(P<0.001)$ and a significant interaction between years and cultivars was observed $(P=0.0025)$. Cultivars Hamlet $(P=0.03)$, Highlander $(P<0.001)$, Pulsar $(P=0.017)$, Redwing $(P=0.014)$, and Stanley $(P=0.006)$ had significantly higher final disease incidence in 2011 compared with that in 2012 (Table 1).

Leaf and neck anthracnose severity progression over time (represented by the mean SAUDPC values) was significantly different among cultivars $(P<0.001)$, and a significant interaction among cultivars and years was observed $(P=0.02)$. However, the number of onion plants per plot was a significant covariate with slopes different from zero $(P=$ 0.0089 ) but with similar slopes among cultivars $(P=0.1262)$. After the covariate was included in the model, the interaction between cultivar and year changed $(P=0.057)$. Only two cultivars, Hendrix and Marco, had differences in SAUDPC values between years with higher SAUDPC values in 2012 compared with that in 2011 (Table 2).

In both years, Highlander and Candy consistently had the highest mean SAUDPC values when compared with the other 14 cultivars (Table 2). The values for these two cultivars were significantly different from each other in 2012, with 'Highlander' having the highest SAUDPC value, whereas in 2011 , their mean SAUDPC values were similar (Table 2).

After plating, C. coccodes colonies developed from foliar lesions $5 \mathrm{~d}$ after isolations were conducted, and microsclerotia were observed $14 \mathrm{~d}$ later. Among cultivars, microsclerotia were not evident on onion roots at the time of field collection. After incubating onion root isolations for 2 weeks, microsclerotia were observed on cultivars Bradley ( $15 \%$ of the roots), Marco (15\%), Livingston (10\%), Stanley (10\%), Vespucci $(10 \%)$, Hendrix $(5 \%)$, Infinity $(5 \%)$, and Prince (5\%) in 2011. In 2012, microsclerotia were observed on the roots of cultivars Candy $(10 \%)$, Polo $(10 \%)$, Prince $(5 \%)$, Livingston $(5 \%)$, and Stanley (5\%). Six cultivars (Talon, Redwing, Pulsar, Milestone, Highlander and Hamlet) showed no evidence of root infection.

\section{Discussion}

Onion cultivars suitable for Michigan were screened under field conditions and all were susceptible to $C$. coccodes. Disease symptoms were less severe on 'Hendrix' and more severe on 'Highlander' and 'Candy' in both years. Both Candy and Highlander require a relatively short period to maturity and are ready for harvest $2-3$ weeks earlier than the other cultivars included in this study. These early maturing cultivars can be planted later in the spring when field operations have been delayed by poor environmental conditions such as excessive rain. Highlander lodges early and has superior neck closure when compared with other cultivars, but has been rated as an onion with thin skin that cracks easily, and produces an uneven-shaped bulb with an overall poor appearance (McDonald et al., 2009). Currently, 'Highlander' is widely grown in Michigan even though it is also highly susceptible to pink root (Wiriyajitsomboon, 2015).

The uneven plant stand across cultivars was a significant covariate that was included in the statistical analysis (ANCOVA) and the slopes per cultivar in ANCOVA were not significantly different with a positive slope. This indicates the higher the plant density, the higher the disease severity. The number of onions per area and the spatial arrangement of the plants in the plot (clumped plants vs. gaps) have an effect on the microclimate of the plots (temperatures, moisture distribution, and leaf wetness duration) and could impact the inoculum dispersal in space (Boudreau and Madden, 1995; Burdon and Chilvers, 1982; Moral et al., 2012). The effect of planting density on the severity of onion leaf and neck anthracnose could be further investigated, as it has the potential to be used as a cultural disease management tool.

Final onion leaf and neck anthracnose incidence varied between years for cultivars Pulsar, Hamlet, Redwing, Stanley, and 
Table 1. Seed company, days to maturity, and final incidence (\%) of leaf and neck anthracnose on 16 onion cultivars grown in field trials during 2011 and 2012 inoculated with Colletotrichum coccodes.

\begin{tabular}{|c|c|c|c|c|c|c|}
\hline \multirow[b]{2}{*}{ Cultivar } & \multirow[b]{2}{*}{ Company $^{z}$} & \multirow[b]{2}{*}{ Days to maturity } & \multicolumn{4}{|c|}{ Final incidence $(\%)^{y}$} \\
\hline & & & Combined yr & Differences by $\mathrm{yr}^{\mathrm{x}}$ & $201149 \mathrm{DAI}^{\mathrm{w}}$ & 201247 DAI $^{*}$ \\
\hline Infinity & Nunhems & $105-110$ & $48.0 \mathrm{e}$ & NS & $50.2 \mathrm{fg}$ & $43.8 \mathrm{bcd}$ \\
\hline Talon & Bejo & 110 & $49.1 \mathrm{de}$ & NS & 57.2 cdefg & $44.3 \mathrm{bcd}$ \\
\hline Hamlet & Seminis & 105 & $52.1 \mathrm{cde}$ & ** & 69.8 bcde & $36.6 \mathrm{~d}$ \\
\hline Pulsar & Nunhems & $100-105$ & 55.0 bcde & $* *$ & 66.1 bcdef & $43.5 \mathrm{bcd}$ \\
\hline Bradley & Bejo & 118 & 59.9 bcde & NS & $64.6 \mathrm{cdef}$ & $53.5 \mathrm{abcd}$ \\
\hline Redwing & Bejo & 118 & 60.7 bcde & ** & $71.8 \mathrm{bcd}$ & $48.6 \mathrm{bcd}$ \\
\hline Livingston & Solar & $100-110$ & 62.7 abcde & NS & $61.7 \mathrm{cdefg}$ & $64.7 \mathrm{a}$ \\
\hline Candy & Seminis & 95 & 63.8 abcde & NS & $73.3 \mathrm{bc}$ & $55.9 \mathrm{abc}$ \\
\hline Stanley & Solar & $100-110$ & 64.7 abcde & $* *$ & $84.7 \mathrm{ab}$ & $43.3 \mathrm{bcd}$ \\
\hline Prince & Bejo and Solar & 105 & $65.7 \mathrm{ab}$ & NS & $73.7 \mathrm{bc}$ & $56.7 \mathrm{ab}$ \\
\hline Highlander & Takii & $85-90$ & $76.1 \mathrm{a}$ & $* *$ & $94.9 \mathrm{a}$ & $47.3 \mathrm{bcd}$ \\
\hline
\end{tabular}

${ }^{\mathrm{z}}$ Bejo Seeds, Inc., Oceano, CA; Nunhems USA, Parma, ID; Seminis Vegetable Seeds, Inc., St. Louis, MO; Siegers Seed Co., Holland, MI; Solar Seed, Inc., Eustis, FL; American Takii, Inc., Salinas, CA.

${ }^{\mathrm{y}}$ Mean percentage of infected plants per cultivar.

${ }^{\mathrm{x}}$ For each cultivar, asterisks indicate that final incidence differed significantly on the cultivar $\times$ year interaction alpha $=0.05$.

${ }^{\mathrm{w}} \mathrm{DAI}=$ days after inoculation.

${ }^{\mathrm{v}}$ Means within a column followed by the same letter are not significantly different (least significant difference).

Table 2. Mean area under the disease progress curve for severity (SAUDPC) values for onion leaf and neck anthracnose severity of 16 onion cultivars grown in field trials inoculated with Colletotrichum coccodes during 2011 and 2012.

\begin{tabular}{lcccc}
\hline & \multicolumn{5}{c}{ Mean SAUDPC $^{\mathrm{z}}$} \\
\cline { 2 - 5 } Cultivar & Combined yr & Differences by yr $\mathrm{yr}^{\mathrm{y}}$ & 2011 mean & $2012 \mathrm{mean}$ \\
\hline Hendrix & $51.5 \mathrm{f}^{\mathrm{x}}$ & $* *$ & $41.2 \mathrm{a}$ & $61.9 \mathrm{ab}$ \\
Talon & $52.9 \mathrm{ef}$ & NS & $57.3 \mathrm{abc}$ & $48.4 \mathrm{a}$ \\
Polo & $55.1 \mathrm{ef}$ & NS & $58.4 \mathrm{abc}$ & $51.9 \mathrm{a}$ \\
Redwing & $56.5 \mathrm{ef}$ & NS & $61.7 \mathrm{bc}$ & $51.2 \mathrm{a}$ \\
Vespucci & $57.4 \mathrm{ef}$ & NS & $51.6 \mathrm{abc}$ & $63.2 \mathrm{ab}$ \\
Hamlet & $57.6 \mathrm{ef}$ & NS & $66.3 \mathrm{bc}$ & $48.9 \mathrm{a}$ \\
Infinity & $58.1 \mathrm{ef}$ & NS & $56.5 \mathrm{abc}$ & $59.7 \mathrm{ab}$ \\
Livingston & $59.6 \mathrm{ef}$ & NS & $62.0 \mathrm{bc}$ & $57.1 \mathrm{ab}$ \\
Pulsar & $61.9 \mathrm{ef}$ & NS & $61.6 \mathrm{bc}$ & $62.2 \mathrm{ab}$ \\
Prince & $62.3 \mathrm{ef}$ & NS & $64.5 \mathrm{bc}$ & $60.1 \mathrm{ab}$ \\
Stanley & $64.1 \mathrm{def}$ & NS & $71.5 \mathrm{bc}$ & $56.8 \mathrm{ab}$ \\
Milestone & $64.2 \mathrm{de}$ & NS & $65.6 \mathrm{bc}$ & $62.9 \mathrm{ab}$ \\
Bradley & $79.1 \mathrm{~cd}$ & NS & $80.7 \mathrm{c}$ & $77.6 \mathrm{bc}$ \\
Marco & $79.8 \mathrm{c}$ & $* *$ & $65.0 \mathrm{bc}$ & $94.6 \mathrm{c}$ \\
Candy & $102.3 \mathrm{~b}$ & NS & $105.7 \mathrm{~d}$ & $98.8 \mathrm{c}$ \\
Highlander & $125.0 \mathrm{a}$ & NS & $123.5 \mathrm{~d}$ & $126.6 \mathrm{~d}$ \\
\hline
\end{tabular}

${ }^{\mathrm{z}}$ Mean SAUDPC calculated using whole plot severity rating assessed 12, 21, 27, 35, 42, 49, and $56 \mathrm{~d}$ after inoculation (DAI) in 2011 and 16, 35, 42, 47, and 56 DAI in 2012.

${ }^{\mathrm{y}}$ For each cultivar, asterisks indicate that final incidence and mean SAUDPC differed significantly on the cultivar-year interaction $\alpha=0.01$.

${ }^{\mathrm{x}}$ Means within a column followed by the same letter are not significantly different (least significant difference).

Highlander, where incidence was significantly higher in 2011 compared with 2012 (Table 1). Cultivars Pulsar and Stanley had significant differences in the plant stand between years, but cultivars Redwing and Highlander had homogeneous densities. For 14 of the 16 cultivars, the onion seed used for 2011 originated from growers and may have been from the previous year's seed lot. Onion seed is known to be short-lived (MohamedYasseen et al., 1994), and old seed (stored for one to two seasons or more) could have resulted in decreased germination and an unequal plant stand.

Disease incidence observed on 'Hamlet', 'Redwing', and 'Highlander' differed between years. Air temperatures for both years were favorable for disease development with August temperatures averaging between 21.2 (2011) and $20.7{ }^{\circ} \mathrm{C}$ (2012). Colletotrichum spp. optimal mycelial growth occurs from 18 to $30{ }^{\circ} \mathrm{C}$ (Dillard, 1988; Thomas et al., 2008; Thompson and Jenkins, 1985; Wharton and Diéguez-Uribeondo, 2004). Lesion formation and disease severity occur in a similar temperature range but vary among Colletotrichum spp. (King et al., 1997; Leandro et al., 2003; Moral et al., 2012; Thompson and Jenkins, 1985). Colletotrichum orbiculare optimal infection in watermelon occurs from 21 to $24{ }^{\circ} \mathrm{C}$ (Monroe et al., 1997), whereas lesion formation in cucumber foliage occurs from 20 to $28^{\circ} \mathrm{C}$ (Thompson and Jenkins, 1985). Colletotrichum truncatum optimal anthracnose development in lentil occurs at temperatures between 20 and $24{ }^{\circ} \mathrm{C}$ (Chongo and Bernier, 2000). In onion, C. coccodes infected and caused lesions from 15 to $30^{\circ} \mathrm{C}$ but disease severity was greater at $25^{\circ} \mathrm{C}$ (Rodríguez-Salamanca et al., 2018).

C. coccodes was recovered from roots of several onion cultivars in our study, even though microsclerotia were not observed at collection time. Microsclerotia were observed $14 \mathrm{~d}$ after plating the roots, with $C$. coccodes recovery percentage ranging from $5 \%$ to $15 \%$. Although onion is a low organic residue crop, $C$. coccodes could overwinter in onion roots left behind after harvest. Microsclerotia in roots could contribute to soilborne inoculum, as it does in tomatoes and potatoes (Dillard and Cobb, 1998; Lees et al., 2010). Survival and persistence of this inoculum can be influenced by residue location in the soil profile and soil management after onion harvest (Dillard and Cobb, 1998). When foliar fungicides were applied to tomatoes, the number of C. coccodes-infected root segments decreased (Dillard and Cobb, 1997) and could, thereby, reduce $C$. coccodes soilborne inoculum. Michigan growers typically use celery or carrot as a rotational crop for onion. Neither potatoes nor tomatoes, crops commonly infected by C. coccodes, are commonly grown in the state's onionproducing regions.

Currently, Michigan onion growers rely on fungicides to limit loss incited by $C$. coccodes. When eight fungicides were tested for efficacy in an inoculated field trial conducted in 2011, applications of chlorothalonil or azoxystrobin limited foliar disease significantly compared with the untreated inoculated control; azoxystrobin was significantly more effective than chlorothalonil. Only applications of azoxystrobin resulted in a significantly increased yield compared with the untreated inoculated control.

Screening commercial onion cultivars for their susceptibility to $C$. coccodes is a first step to identify existing cultivars with 
resistance to onion leaf and neck anthracnose. Additional sources of resistance could be available in wild relatives of $A$. cepa. For instance, A. cepa relatives Allium fistulosum, Allium galanthum, and Allium roylei showed partial levels of resistance to C. gloeosporioides (Galvan et al., 1997). In addition, cultivars resistant to $C$. coccodes need the desired market quality characteristics suitable for Michigan.

In conclusion, the combination of host resistance, effective fungicide sprays, and cultural practices (pathogen-free seed, crop rotation, weed control, plant spacing, and timed and limited irrigation) is key for the management of onion leaf and neck anthracnose. Michigan growers could consider replacing disease-susceptible cultivars such as 'Highlander' with a less susceptible cultivar.

\section{Literature Cited}

Anderson, R.N. and H.L. Walker. 1985. Colletotrichum coccodes: A pathogen of eastern black nightshade (Solanum ptycanthum). Weed Sci. 33:902-905.

Ben-Daniel, B-h., D. Bar-Zvi, and L. Tsror. L. 2010. Transmission of Colletotrichum coccodes via tomato seeds. Phytoparasitica 38:167174.

Bird, G., M.K. Hausbeck, L. Jess, W. Kirk, Z. Szendrei, and F. Wagner. 2012. Insect, disease and nematode control for commercial vegetables. Mich. State Univ. Ext. Bul. E312.

Boudreau, M.A. and L.V. Madden. 1995. Effect of strawberry density on dispersal of Colletotrichum acutatum by simulated rain. Phytopathology 85:934-941.

Burdon, J.J. and G.A. Chilvers. 1982. Host density as a factor in plant disease ecology. Annu. Rev. Phytopathol. 20:143-166.

Carisse, O., D-M. Tremblay, M.R. McDonald, L. Brodeur, and N. McRoberts. 2011. Management of Botrytis leaf blight of onion: The Quebec experience of 20 years of continual improvement. Plant Dis. 95:504-514.

Chongo, G. and C.C. Bernier. 2000. Effects of host, inoculum concentration, wetness duration, growth stage, and temperature on anthracnose of lentil. Plant Dis. 84:544-548.

Develash, R.K. and S.K. Sugha. 1997. Management of downy mildew (Peronospora destructor) of onion (Allium cepa). Crop Protection 16:63-67.

Dillard, H.R. 1988. Influence of temperature, $\mathrm{pH}$, osmotic potential, and fungicide sensitivity on germination of conidia and growth from sclerotia of Colletotrichum coccodes in vitro. Phytopathology 78:1357-1361.

Dillard, H.R. 1989. Effect of temperature, wetness duration, and inoculum density on infection and lesion development of Colletotrichum coccodes on tomato fruit. Phytopathology 79:1063-1066.

Dillard, H.R. 1992. Colletotrichum coccodes: The pathogen and its hosts, p. 225-236. In: J.A. Bailey and M.J. Jeger (eds.). Colletotrichum: Biology, pathology and control. C.A.B. Intl., Wallingford, Oxon, UK.

Dillard, H.R. and A.C. Cobb. 1997. Disease progress of black dot on tomato roots and reduction in incidence with foliar applied fungicides. Plant Dis. 81:1439-1442.

Dillard, H.R. and A.C. Cobb. 1998. Survival of Colletotrichum coccodes in infected tomato tissue and in soil. Plant Dis. 82:235-238.
Ebenebe, A.C. 1980. Onion twister disease caused by Glomerella cingulata in northern Nigeria. Plant Dis. 64:1030-1032.

Farley, J.D. 1976. Survival of Colletotrichum coccodes in soil. Phytopathology 66:640-641.

Farr, D.F. and A.Y. Rossman. 2011. Fungal databases, systematic mycology and microbiology laboratory. USDA, ARS. 6 Jan. 2011. <http:// nt.ars-grin.gov/fungaldatabases/>.

Galvan, G. 2010. Screening onions and related species for resistance to anthracnose (C. gloeosporoides), p. 309-319. In: Mass screening techniques for selecting crop resistance to disease. Intl. Atomic Energy Agency, Vienna, Austria. $<$ https://www-pub.iaea.org/MTCD/ Publications/PDF/TDL-001_web.pdf $>$.

Galvan, G.A., W.A. Wietsma, S. Putrasemedja, A.H. Permadi, and C. Kik. 1997. Screening for resistance to anthracnose (Colletotrichum gloeosporioides Penz.) in Allium cepa and its wild relatives. Euphytica 95:173-178.

Haddad, F., L.A. Maffia, and E.S.G. Mizubuti. 2003. Evaluation of fungicides to control $\mathrm{Col}$ letotrichum gloeosporioides on onion. Fitopatol. Bras. 28:435-437.

Hughes, S.J. 1958. Revisiones hyphomycetum aliquot vum appendice ce nominibus rejiciendis. Can. J. Bot. 36:727-836.

King, W.T., L.V. Madden, M.A. Ellis, and L.L. Wilson. 1997. Effects of temperature on sporulation and latent period of Colletotrichum spp. infecting strawberry fruit. Plant Dis. 81:77-84.

Leandro, L.F.S., M.L. Gleason, F.W. Nutter, S.N. Wegulo, and P.M. Dixon. 2003. Influence of temperature and wetness duration on conidia and appressoria of Colletotrichum acutatum on symptomless strawberry leaves. Phytopathology 93:513-520.

Lees, A.K., J.L. Brierley, J.A. Stewart, A.J. Hilton, S.J. Wale, P. Gladders, N.J. Bradshaw, and J.C. Peters. 2010. Relative importance of seed-tuber and soilborne inoculum in causing black dot disease of potato. Plant Pathol. 59:693-702.

McDonald, M.R., S. Janse, and K. Vander Kooi. 2009. Muck vegetable cultivar trial \& research report. Univ. Guelph, Canada. $<$ https://atrium. lib.uoguelph.ca/xmlui/bitstream/handle/10214/ 3782/2009_Muck_Vegetable_and_Research_ Report.pdf? sequence=3\&isAllowed $=y>$.

Mohamed-Yasseen, Y., S.A. Barringer, W.E. Splittstoesser, and S. Costanza. 1994. The role of seed coats in seed viability. Bot. Rev. 60:426-439.

Monroe, J.S., J.B. Santini, and R. Latin. 1997. A model defining the relationship between temperature and leaf wetness duration, and infection of watermelon by Colletotrichum orbiculare. Plant Dis. 81:739-742.

Moral, J., J. Jurado-Bello, M.I. Sanchez, R. de Oliveira, and A. Trapero. 2012. Effect of temperature, wetness duration, and planting density on olive anthracnose caused by Colletotrichum spp. Phytopathology 102:974-981.

Natural Resources Conservation Serv. (n.d.) Web soil survey. Soil Survey Staff, U.S. Dept. Agr. 27 Mar. 2011. <http://websoilsurvey.nrcs. usda.gov/>.

Nischwitz, C., D.B. Langston, Jr., H.F. Sanders, R. Torrance, K.J. Lewis, and R.D. Gitaitis. 2008 First report of Colletotrichum gloeosporioides causing "twister disease" of onion (Allium cepa) in Georgia. Plant Dis. 92:974.

Nitzan, N., T.F. Cummings, and D.A. Johnson. 2008. Disease potential of soil- and tuberborne inocula of Colletotrichum coccodes and black dot severity on potato. Plant Dis. 92:14971502 .
Raid, R.N. and S.P. Pennypacker. 1987. Weeds as hosts for Colletotrichum coccodes. Plant Dis. 71:643-646.

Raniere, L.C. and D.F. Crossan. 1959. The influence of overhead irrigation and microclimate on Colletotrichum phomoides. Phytopathology 49:72-74.

Robert, V., G. Stegehuis, and J. Stalpers. 2005. The MycoBank engine and related databases. $<$ http://www.mycobank.org/>.

Rodríguez-Salamanca, L.M. 2013. Characterization, virulence, epidemiology, and management of Colletotrichum spp. causing anthracnose in onion and celery. Michigan State Univ., East Lansing, PhD Diss. ProQuest document ID 1491163201. <http://ezproxy.msu.edu.proxy2. cl.msu.edu/login?url=https://search-proquestcom.proxy2.cl.msu.edu/docview/1491163201? accountid $=12598>$.

Rodríguez-Salamanca, L.M., T.B. Enzenbacher, M. Derie, L. du Toit, C. Feng, J.C. Correll, and M.K. Hausbeck. 2012. First report of Colletotrichum coccodes causing leaf and neck anthracnose on onions (Allium cepa) in Michigan. Plant Dis. 96:769.

Rodríguez-Salamanca, L.M., R.P. Naegele, L.M. Quesada-Ocampo, and M.K. Hausbeck. 2018. Inoculation methods, temperature, and relative humidity affect leaf and neck anthracnose, a new onion disease in Michigan. Plant Health Prog. 19:64-68

Schwartz, H.F., L.J. du Toit, and T. Coutinho. 2015. Common names of plant diseases: Diseases of onion and garlic (Allium cepa $\mathrm{L}$. and $A$. sativum L., respectively). Amer. Phytopathol. Soc., St. Paul, MN. <http://www.apsnet.org/ publications/commonnames/Pages/OnionandGarlic.aspx>.

Schwartz, H.F. and K.S. Mohan. 1995. Compendium of onion and garlic diseases and pests. Amer. Phytopathol. Soc., St. Paul, MN.

Schwartz, H.F. and K.S. Mohan. 2008. Compendium of onion and garlic diseases and pests. 2nd ed. Amer. Phytopathol. Soc., St. Paul, $\mathrm{MN}$.

Sutton, B.C. 1980. The Coelomycetes: Fungi imperfecti with pycnidia, acervuli and stromata. CABI Intl., New York, NY.

Thomas, G.J., M.W. Sweetingham, H.A. Yang, and J. Speijers. 2008. Effect of temperature on growth of Colletotrichum lupini and on anthracnose infection and resistance in lupins. Australas. Plant Pathol. 37:35-39.

Thompson, D.C. and S.F. Jenkins. 1985. Effect of temperature, moisture, and cucumber cultivar resistance on lesion size increase and conidial production by Colletotrichum lagenarium. Phytopathology 75:828-832.

Tsror (Lahkim), L. and D.A. Johnson. 2000. Colletotrichum coccodes on potato, p. 362 373. In: S.F. Dov Prusky and M.B. Dickman (eds.). Colletotrichum, host specificity, pathology, and host-pathogen interaction. Amer. Phytopathol. Soc. Press, St. Paul, MN.

Wharton, P.S. and J. Diéguez-Uribeondo. 2004 The biology of Colletotrichum acutatum. Jardín Botanico de Madrid 61:3-22.

Wiriyajitsomboon, P. 2015. Characterization of Setophoma terrestris causing pink root in onion, disease management, and age-related resistance. Michigan State Univ., East Lansing, PhD Diss. ProQuest document ID 1749035499. $<$ http://ezproxy.msu.edu.proxy2.cl.msu.edu/login? url=https://search-proquest-com.proxy2.cl.msu. edu/docview/1749035499? accountid=12598>. 